\title{
Tree Crown Variation and Seasonal in the Phenolic Compounds Content of Stryphnodendron adstringens (Mart) Coville Leaves
}

\author{
Alessandra de Oliveira Ribeiro ${ }^{1 *}$, Selma Lopes Goulart ${ }^{1}$, Fábio Akira Mori ${ }^{1}$, \\ Ana Hortência Fonseca Castro ${ }^{2}$ \\ ${ }^{1}$ Department of Forest Sciences, Federal University of Lavras, Campus Universitário, Lavras, Brazil \\ ${ }^{2}$ Pharmacy Department, Natural Products Laboratory, Federal University of São João Del Rei, \\ Divinópolis, Brazil \\ Email: alebioribeiro@gmail.com
}

Received 18 July 2014; revised 21 August 2014; accepted 12 September 2014

Copyright (C) 2014 by authors and Scientific Research Publishing Inc.

This work is licensed under the Creative Commons Attribution International License (CC BY). http://creativecommons.org/licenses/by/4.0/

(c) (i) Open Access

\begin{abstract}
The aim of this study was to compare phenolic compounds contents between different positions within the crown and between collection periods, and to evaluate the tannin contents by the Folin-Ciocalteu method. The collections were performed in Lavras, in the southern region of the Brazilian state Minas Gerais. The experiment was conducted in a completely randomized design (factorial $3 \times 4$ ); the first factor being the position (base, middle, top); and the months, the second factor (February, May, September and December). We verified that the leaves of $S$. adstringens present higher total phenolic and tannin contents at the top $(23.05 \%$ and $18.23 \%)$ and base $(21.42 \%$ and $16.61 \%)$ of the crown, in May (25.79\% and $20.85 \%)$ and September (25.57\% and $20.50 \%)$, respectively. There was no difference in the residual phenol and flavonoid contents between the positions within the crown or in the months of collection. These facts suggest that within the crown and climatic changes may be one of the factors affecting phenol levels in Stryphnodendron adstringens.
\end{abstract}

\section{Keywords}

Barbatimão, Tannins, Leaves, Seasonal Variation, Cerrado

\footnotetext{
"Corresponding author.
} 


\section{Introduction}

The Cerrado is a biome that stands out for its biodiversity, having a great extension and diverse vegetal heterogeneity [1]. However, it is one of the most threatened biomes in the planet, due to the rate at which human activity is transforming natural areas [2].

Stryphnodendron adstringens (Mart) Coville, one of the native species of the Cerrado, is popularly known as "barbatimão". The main economic use of this species is tannin extraction from the bark and leaves. This species has many uses in popular medicine [3], due to their therapeutic properties as gastric antiulcerogenic, [4] [5] trypanocidal, [6] antimicrobial, [7]-[9] antioxidant [10] [11] and as wound healing [12].

Tannins are phenolic compounds formed from the secondary metabolism of plants and are biosynthesized by the shikimic acid pathway [13]. They are important in the vegetable's defense mechanism against solar radiation and herbivory. In addition, the total phenol and flavonoids are also produced by the plant, and are important to its growth and reproduction. These compounds are also formed under some adverse conditions, like injuries [14], and their contents vary according to plant tissues, age and size of the plant, the fragment collected, and season or collection site [15].

In their habitat, these plants are exposed to intense solar radiation, which degrades extremely important molecules for the photosynthetic processes through photo-oxidation, such as chlorophylls and other pigments. To protect themselves against this radiation, plants synthesize phenolic compounds, which absorb the radiation on the epidermal layers of the leaf tissues, regulating the antioxidant system in the cells. The concentration of these compounds in the vegetable can be influenced by several factors, such as water stress, temperature, light and circadian rhythm [16].

Several environmental factors vary with different positions in a plant crown [17]. These differences of environmental factors also bring different stresses for leaves in different canopy positions. Previous studies about this species that refer to the variation in the tannin contents in different positions within the crown are important to determine the position in which they are produced more intensely, and facilitate understanding of ecophysiological adaptations, besides contributing to the increase of scientific knowledge of this native species.

In this regard, the aim of this study was to compare phenolic compounds contents between different positions within the crown and across different collection periods.

\section{Materials and Methods}

\subsection{Study Area}

The study was performed from February to December 2010, in a Cerrado fragment in Lavras, in the southern region of the Brazilian state of Minas Gerais. The meteorological data regarding temperature, precipitation and insolation were collected in the main Climate Station at Federal University of Lavras.

\subsection{Botanical Material Sampling}

We collected leaves from the crown of each individual, dividing each crown into base, middle and top, according to (Figure 1). Reference material was incorporated into the Herbarium (ESAL), Department of Biology, Federal University of Lavras.

\subsection{Extract Preparation and Determination of Phenolic Compound Contents by the Method of Folin-Ciocalteu}

$200 \mathrm{mg}$ of ground leaf tissue were used after being extracted in $10 \mathrm{~mL}$ of methanol 50\% at room temperature on a magnetic stirrer (150 rpm) for $4 \mathrm{~h}$, following the methodology described by [18]. The final extract volume was completed to $10 \mathrm{~mL}$. The samples were processed in triplicates.

We employed the standard protocol of [19] with some modifications to obtain the total and residual phenolic contents. The difference between these contents constitutes the total tannin content of the vegetable. For the dosing of total phenol, $0.1 \mathrm{~mL}$ from the crude extract was transferred to a 15-mL test tube, in which $0.5 \mathrm{~mL}$ of Folin-Ciocalteu reagent at $10 \%(\mathrm{v} / \mathrm{v})$ and $1.0 \mathrm{~mL}$ of sodium carbonate aqueous solution at $7.5 \%(\mathrm{w} / \mathrm{v}) \mathrm{were}$ added, completing the volume with distilled water. After 30 minutes, we measured the absorbance with a spectrophotometer with a 760-nm wavelength. 


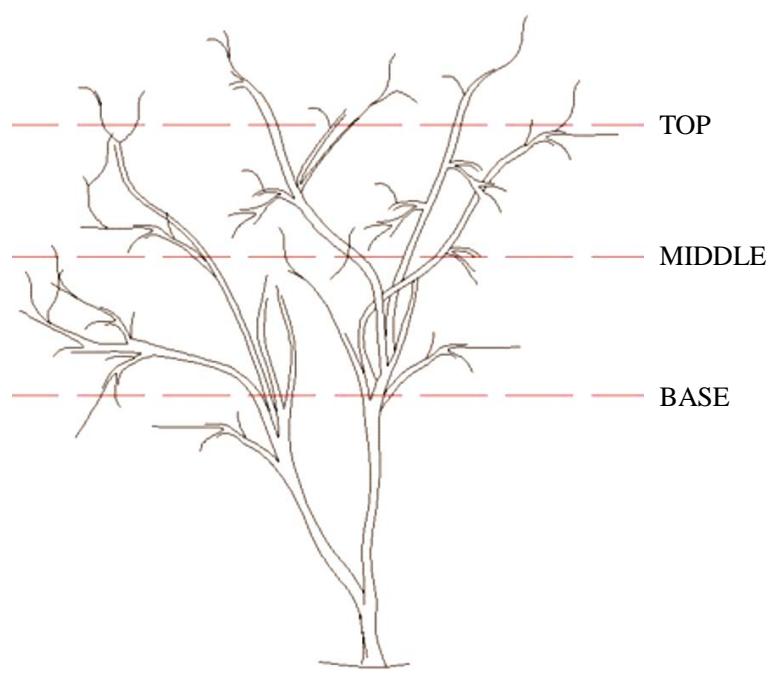

Figure 1. Schematic representation of leaf-gathering of $S$. adstringens in different positions within the crown.

Subsequently, in a $25 \mathrm{~mL}$ Erlenmeyer flask, $6 \mathrm{~mL}$ of crude extract, $10 \mathrm{~mL}$ of distilled water and $1 \mathrm{~g}$ of casein were mixed. The sample was agitated for three hours so as to stimulate the complex formation of tannins through the tannin-protein link. After this period, the contents were filtrated through 9-mm Whataman filter paper into a $25 \mathrm{~mL}$ volumetric flask, adding distilled water to the filtrated content until the volume was complete. $0.5 \mathrm{~mL}$ of this solution was transferred to a test tube, and the same procedure described for total phenol dosing was used, obtaining the concentration of residual phenol, according to the standard protocol of [19].

\subsection{Histochemical Tests}

Histochemical tests on leaves were performed to verify the chemical composition of the cell wall in sections of material newly collected and not fixed. The sections were obtained freehand and treated with hydrochloric acid and vanillin $9 \%$ for the identification of tannins [20].

\subsection{Determination the Total Flavonoid Contents}

The total flavonoid assay was performed using as a standard solution of $100 \mu \mathrm{g} \cdot \mathrm{mL}^{-1}$ rutin in a methanol solution of $2 \%$ aluminum chloride, based on the construction of a calibration curve [21]. An aliquot of $100 \mu \mathrm{L}$ of hydromethanolic extract was used for spectrophotometric determination. Readings were taken at $425 \mathrm{~nm}$ and all determinations were made in triplicate. The result was expressed in percentage of flavonoids per gram of dry matter.

\subsection{Statistical Analysis}

The experiment was developed using a completely randomized design in factorial $3 \times 4$, with the position as the first factor (base, middle or top), and the month as the second factor (February, May, September or December).

The data from the experiment were analyzed with variance analysis and a Tukey's test, both at a 5\% significance level. The analyses were performed using the SISVAR 4.2 software [22].

Principal component analysis (PCA) was by using PCORD to study the interaction between climatic data and phenolic compounds content and Cluster analysis (CA) for the similarity analysis of phenolic compounds in different strata of the canopy were statistic 5.0.

\section{Results and Discussion}

\subsection{Phenolic Compounds Content of Position Crown}

Statistical differences were observed in the total phenolics and tannin contents through the Folin-Ciocalteu me- 
thod, between the different positions analyzed within the crown $(\mathrm{p}<0.05)$ (Table 1).

The leaves located in the top and base of the crown presented higher total phenolic and tannin contents (23.05\% and $18.23 \%, 21.42 \%$ and $16.61 \%$, respectively). This was statistically different from the middle of the crown, which presented lower total phenolics $(17.10 \%)$ and tannin contents $(12.35 \%)$. The fact that the highest concentrations of total phenol and tannins are located on the top and base of the crown is possibly because of photoprotective mechanisms that the individuals of $S$. adstringens utilize to protect from excess radiation. Since the crowns of barbatimão present irregular shape, there is a greater emission of photons, both at the top and base of the crown. In the middle of the crown, the concentrations of total phenol and tannins were lower and statistically different. Such fact can be justified by the reduced need to synthesize tannin molecules, once the light penetration is reduced in that area.

Histochemical analysis reveals the distribution of tannins in leaf tissues between the different positions of the crown as (Figure 2), showing its presence in both the epidermis and the palisade and spongy parenchyma, in greater proportion at the top followed by the base of the crown, corroborating the results obtained by the Folin Ciocalteu colorimetric method.

Aiming to protect from this radiation, plants of $S$. adstringens synthesize phenolic compounds, like tannins, which has $254 \mathrm{~nm}$ of wavelength. This way, these compounds act in the absorption of radiation in the epidermal layers of the leaf tissues, regulating the antioxidant system in the cells [23].

In relation to residual phenol contents, denominated non-tannin phenols, differences between the positions within the crown were not observed: base (4.79\%), middle (4.75\%) and top (4.82\%). By analyzing other non-tannin phenols, like flavonoids belonging to this class of phenolic compounds, it can be observed that they presented the same pattern as residual phenols, detecting no differences in the flavonoids contents between the analyzed positions. The top of the crown presented $3.50 \%$, the base $3.28 \%$ and the middle $2.70 \%$.

Cluster analysis based on the contents of phenolic compounds in the leaves ordered positions of the canopy into two distinct groups (Figure 3).

A group middle the contents present in the canopy and the other group brought together the top and base contents of the canopy. From this result we can infer that there was a greater focus on the contents of total phenolic and tannin contents, this being brought together in a single group.

Table 1. Average total phenolics, residual phenol, tannins and flavonoid contents among the trees of S. adstringens, in different positions within the crown in (\%).

\begin{tabular}{ccccc}
\hline Position & Total phenol & Residual phenol & Total tannins & Flavonoids \\
\hline Base & $21.42 \mathrm{~b}$ & $4.79 \mathrm{a}$ & $16.61 \mathrm{~b}$ & $3.28 \mathrm{a}$ \\
Middle & $17.10 \mathrm{a}$ & $4.75 \mathrm{a}$ & $12.35 \mathrm{a}$ & $2.70 \mathrm{a}$ \\
Top & $23.05 \mathrm{~b}$ & $4.82 \mathrm{a}$ & $18.23 \mathrm{~b}$ & $3.50 \mathrm{a}$ \\
Average & 20.52 & 4.79 & 15.73 & 3.16 \\
\hline
\end{tabular}

Averages followed by the same letter do not differ by Tukey’s test at a $5 \%$ significance level.

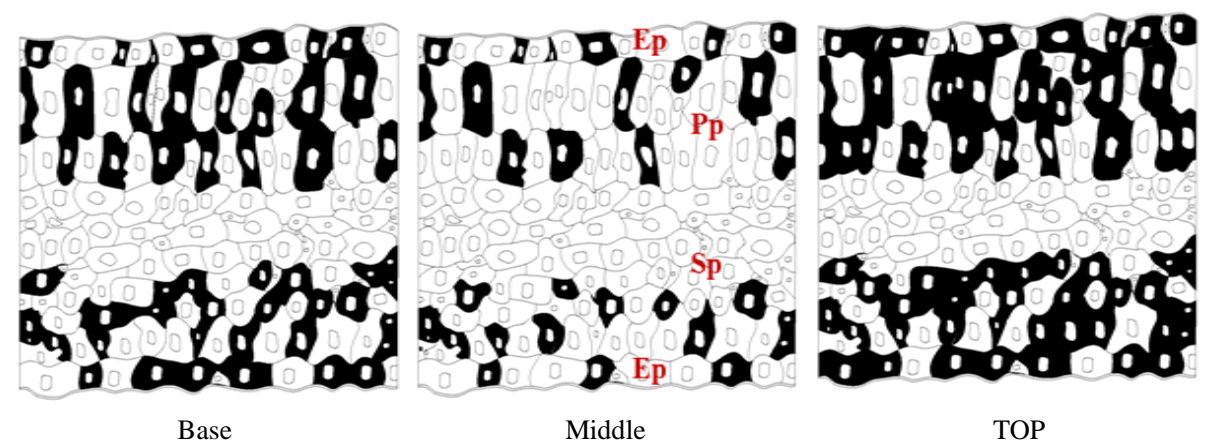

Figure 2. Schematic representation of the distribution of tannins in leaf tissues of S. adstringens, in different positions within the crown. (Ep) epidermis; (Pp) palisade parenchyma; (Sp) spongy parenchyma. 


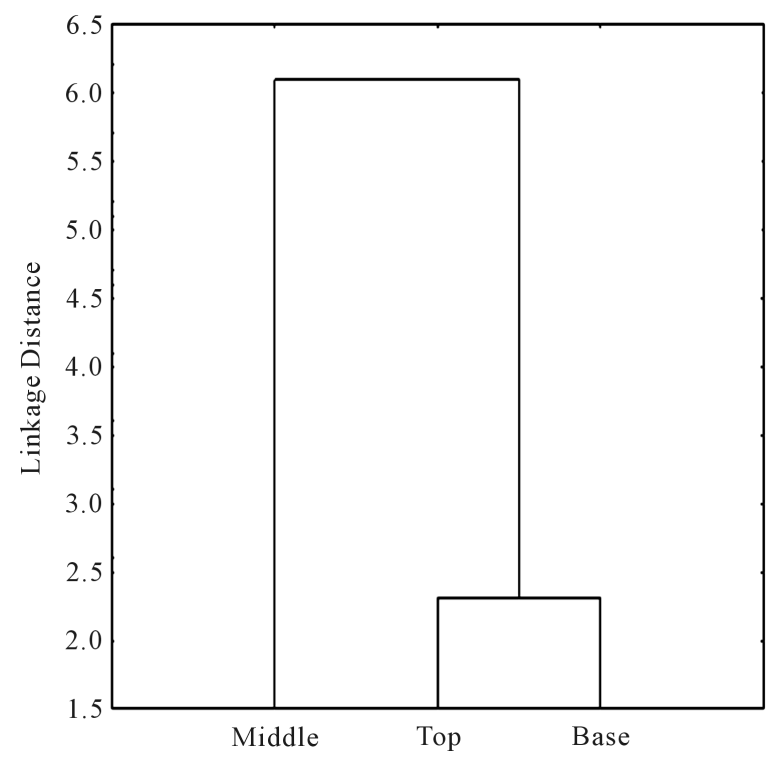

Figure 3. Dendrogram representing the similarity relationships of chemical composition among positions the crown analyzed for $S$. adstringens to which clusters belong.

By analyzing other non-tannin phenols, like flavonoids belonging to this class of phenolic compounds, we observed the same pattern as residual phenols, with no differences in the flavonoid contents between the positions analyzed, possibly due to the way the quantity of tannins is calculated with the Folin-Ciocalteu method: first, the total phenols are measured, then tannins are removed from the extract through protein precipitation, leaving the residual phenols. The final value of tannin contents in the samples is given by the difference between the total and residual phenolic contents [19]. The top of the crown presented $3.50 \%$, the base $3.28 \%$ and the middle $2.70 \%$. Like flavonoids, differences in the residual phenol contents were not observed among the positions analyzed within the crown. [24] relates that the hypothesis of the phenolic compounds protective function against UV radiation is supported by the increment in flavonoids contents in plants exposed to strong radiation, although, in this study, differences in the contents of this compound along the crown were not observed.

\subsection{Phenolic Compounds Content of Climatological Periods}

The PCA results arising in Figure 4 show the distribution of phenolic compounds and their relative position in the sampling period. The axes 1 and 2 represented $93.84 \%$ of the total variance in the data set.

Axis 1 explains $82.78 \%$ of total variance and shows a strong correlation between the phenolic compounds and the temperature, precipitation and insolation and are related to samples collected during the dry season (May and Sept). Axis 2 explained $11.6 \%$ of the total variance and show the clustering behavior along this axis, between the phenolic compounds and the environmental variables.

Higher total phenolic and tannin contents were observed in leaves collected in May and September (Table 2).

In May, these contents were $25.79 \%$ and $20.85 \%$ and in September, $25.57 \%$ and $20.50 \%$, respectively. The climatological data presented in Table 2 show that May and September presented temperatures of $18.7^{\circ} \mathrm{C}$ and $21.6^{\circ} \mathrm{C}$ and rainfall indices of $19.9 \mathrm{~mm}$ and $127.8 \mathrm{~mm}$, which were lower than the other months, leading to a higher concentration of phenolic compounds.

In studies with Eugenia uniflora L. production of tannins was also higher in the dry season, the author reports that this fact is probably in response to the combination of higher incidence of light and drought stress [25]. Seasonal variations in leaf tannins have already been reported for deciduous trees from temperate climates, such as Quercus robur [26] and Betula pubescens [27]. In these studies, phenol variations were related to leaf growth and development, as well as to herbivore pressure. Besides abiotic factors, other factors may influence the contents of these phenolic compounds, like herbivory. When herbivores feed on leaves, the leaf tissues are damaged and the tannins react with proteins, making the leaves less susceptible to the digestive juice of animals [28]. This 


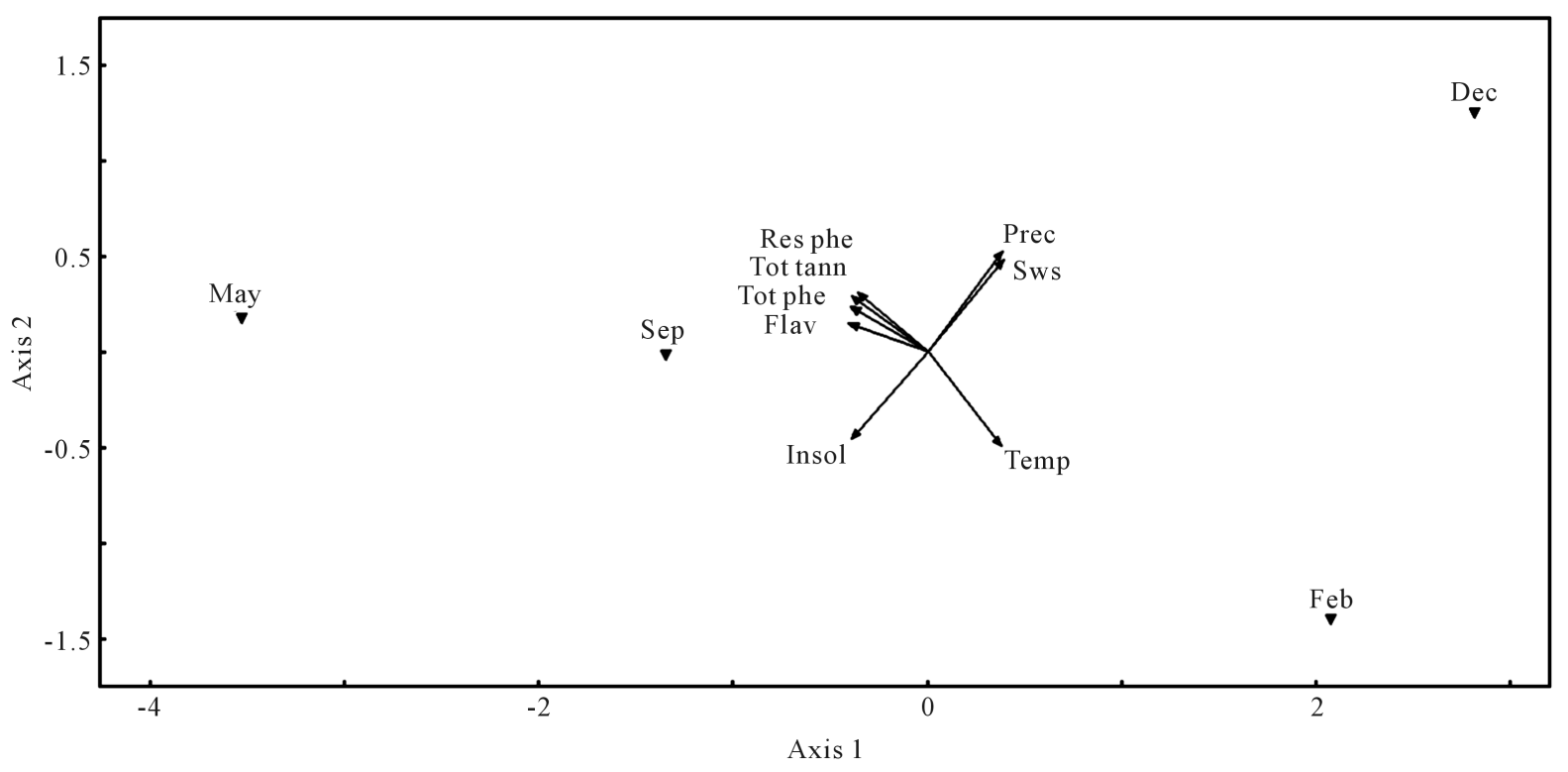

Figure 4. Principal Component scatter plot of sampling months for S. adstringens. Res phe: Residual phenol; Tot tann: Total tannins; Tot phe: Total phenol; Flav: Flavonoids; Prec: Precipitation; Sws: Soil water storage; Temp: Temperature; Insol: Insolation.

Table 2. Variation in the total phenols, residual phenols, tannins and flavonoid contents, analyzed in different months in (\%) and climatic data.

\begin{tabular}{ccccccccc}
\hline Months & TP & RP & T & Flav & Temp $\left({ }^{\circ} \mathrm{C}\right)$ & Rain $(\mathrm{mm})$ & Insol (h) & S.w.s $(\mathrm{mm})$ \\
\hline Feb & $19.25 \mathrm{a}$ & $4.94 \mathrm{a}$ & $13.72 \mathrm{a}$ & $2.19 \mathrm{a}$ & 24.2 & 181.7 & 191.80 & 195.8 \\
May & $25.79 \mathrm{~b}$ & $5.53 \mathrm{a}$ & $20.85 \mathrm{~b}$ & $3.33 \mathrm{a}$ & 18.7 & 19.9 & 222.20 & 25.4 \\
Sept & $25.57 \mathrm{~b}$ & $5.07 \mathrm{a}$ & $20.50 \mathrm{~b}$ & $3.22 \mathrm{a}$ & 21.6 & 127.8 & 202.60 & 125.3 \\
Dec & $20.22 \mathrm{a}$ & $5.04 \mathrm{a}$ & $15.18 \mathrm{a}$ & $2.25 \mathrm{a}$ & 22.4 & 382.5 & 162.20 & 379.2 \\
Average & 22.71 & 5.15 & 17.56 & 2.75 & 21.7 & 178.0 & 194.7 & 181.04 \\
\hline
\end{tabular}

TP: total phenols; RP: residual phenols; T: tannins; Flav: flavonoids; Temp: temperature; Rain: rainfall; Insol: Insolation; Sws: Soil water storage. Averages followed by the same letter do not differ by Tukey’s test at a 5\% significance level.

way, its accumulation in leaves and fruits make them unpalatable, inhibiting the action of herbivory [29].

[30] found tannin contents in leaves of S. adstringens (12.30\%) lower than those that were found in this study. Jacobson et al. (2005), while evaluating the contents of these compounds in barks of S. adstringens, found higher concentrations of total phenols and tannins in the rainy season. [31] mentioned that the total phenolics and tannin contents were, respectively, 30.8\% and 29.9\%. This demonstrates that most of the phenolic compounds found in $S$. adstringens are tannins, which are directly influenced by edaphoclimatic factors.

Variations in residual phenols and flavonoids (Table 2) were not observed during the months of this study, demonstrating that there was no influence of the seasons on non-tannin phenols and flavonoid contents. These levels in May were 5.53\% and 3.33\%, respectively.

In February and December, lower concentrations of total phenol and tannins were detected, as a result of the high rainfall and high temperatures registered in these months.

According to the sampled results in (Table 2), the months of May and September presented lower water percentage in the soil, with values of $25.4 \%$ and $125.3 \%$, respectively. This hydric deficit may have also influenced the tannin concentration in these months, being inversely proportional. Although in September the soil accumulated about five times more water than in May, there was no statistically significant difference in the tannin production, which was $20.85 \%$ in May and $20.50 \%$ in September.

There was a lower production of phenols and tannins in February and December, confirming that the contents 
of these compounds in the vegetable can be influenced by several abiotic factors, such as hydric deficit, light and temperature. [32] points out that these variables regulate the activity of enzymes present in the primary and secondary metabolisms of the vegetable; for example, the phenylalanine ammonia-lyase (PAL).

[33] relates that lower production of phenols and tannins may be related to annual, monthly and daily variations of temperature, which is one of the factors with the highest influence on the vegetable's growth. This may be due to the temperature being a consequence of other factors, like altitude and season, although there are not many studies on the influence of temperature alone on the production of secondary metabolites [16].

High levels of solar radiation coupled with higher temperatures lead in some cases to modifications in the accumulation of polyphenols in the plant. The resulting modifications make it difficult to determine whether physiological changes related to phenolic synthesis in the plant are caused by the effects of either solar radiation or high temperature. The literature has reported that temperature can be positively or negatively correlated to the accumulation of polyphenols during growth or processing for several plant species [34]. An example of the effect of temperature and light can be seen in the significantly high level of phenolics found in the seed and skin of winter berries compared to summer berries [35].

As mentioned, another environmental factor that interferes with the production of these compounds is the hydric deficit, which frequently has significant consequences on the contents of secondary metabolites in plants (especially tannins). Several findings in the literature indicate that these conditions usually lead to an increase in the production of many types of secondary metabolites [16].

The author also relates that the carbon availability for secondary metabolism may be influenced by the climate and the photosynthetic efficiency of plants in each season. Hence, it is not only the energy provided for carbon assimilation (carbon resources for biosynthesis) but also the quality, namely UV fractions (light intensity), which stimulates the formation and accumulation of certain phenolic compounds in plants [34].

This could explain the lower photosynthetic efficiency, since the species in question is native to the Cerrado, whose microclimate is characterized by elevated temperatures and low water availability [36] [37]. However, low temperatures during winter also limit the photosynthetic rate, restricting the elevated productivity of plants to spring and fall, when new leaf growth occurs. This may also explain the decrease of tannin contents in February and December. According to [38], the contents of these metabolites depend on genetics but can also be determined by environmental conditions.

\section{Conclusions}

The leaves of S. adstringens produce total phenolics and tannins in higher levels on the top and base of the crown in May and September. There were no differences in the residual phenolic and flavonoid contents between the positions within the crown or over the months analyzed.

The tannins in barbatimão show promise economically due to its wide use in folk medicine and can be studied using quantitative techniques relatively easy and inexpensive. Approaches on the influence of seasonality, alternatives for obtaining tannin tree species and comparison of the levels of tannins between parts of the same plant deserve to be explored in more depth in order to guide a more sustainable extraction. These results will probably contribute to better understand the metabolism of phenolics in this species.

\section{Acknowledgements}

I would like to express my gratitude to CNPQ and FAPEMIG for the financial support and scholarships.

\section{References}

[1] Ratter, J.A., Ribeiro, J.F. and Bridgwater, S. (2000) Woody Flora Distribution of the Cerrado Biome: Phytogeography and Conservation Priorities. In: Cavalcanti, T.B. and Walter, B.M.T., Eds., Tópicos atuais em botânica, Sociedade Botânica do Brasil/Embrapa Recursos Genéticos e Biotecnologia, Brasília,12, 340-342.

[2] Klink, C.A. and Machado, R.B. (2005) Conservation of the Brazilian Cerrado. Conservation Biology, 19, 707-713. http://dx.doi.org/10.1111/j.1523-1739.2005.00702.x

[3] Oliveira, A.L.S. and Figueiredo, A.D.L. (2007) Prospecção Fitoquímica das folhas de Stryphnodendron adstrigens (Mart.) Coville (Leguminosae-Mimosoidae). Revista Brasileira de Biociências, 5, 384-386.

[4] Audi, E.A., Toledo, D.P., Peres, P.G., Kimura, E., Pereira, W.K., de Mello, J.C., et al. (1999) Gastric Antiulcerogenic 
Effects of Stryphnodendron adstringens in Rats. Phytotherapy Research, 13, 264-246. http://dx.doi.org/10.1002/(SICI)1099-1573(199905)13:3<264::AID-PTR443>3.0.CO;2-R

[5] Martins, D.T., Lima, J.C. and Rao, V.S. (2002) The Acetone Soluble Fraction from Bark Extract of Stryphnodendron adstringens (Mart.) Coville Inhibits Gastric Acid Secretion and Experimental Gastric Ulceration in Rats. Phytotherapy Research, 16, 427-431. http://dx.doi.org/10.1002/ptr.928

[6] Herzog-Soares, J.D. and Alves, R.K. (2002) Trypanocidal Activity in Vivo of Stryphnodendron adstringens (True Barbatimão) and Caryocar brasiliensis (Pequi). Revista Brasileira de Farmacognosia, 12, 2-4. http://dx.doi.org/10.1590/S0102-695X2002000300001

[7] Audi, E.A. (2004) Biological Activity and Quality Control of Extract and Stem Bark from Stryphnodendron adstringens. Acta Farm Bonaer, 23, 328-333.

[8] Ishida, K., de Mello, J.C., Cortez, D.A., Filho, B.P., Ueda-Nakamura, T. and Nakamura, C.V. (2006) Influence of Tannins from Stryphnodendron adstringens on Growth and Virulence Factors of Candida albicans. Journal of Antimicrobial Chemotherapy, 58, 942-949. http://dx.doi.org/10.1093/jac/dkl377

[9] Santos, V.R., Gomes, R.T., Oliveira, R.R., Cortés, M.E. and Brandão, M.G.L. (2009) Susceptibility of Oral Pathogenic Microorganisms to Aqueous and Ethanolic Extracts of Stryphnodendron adstringens (barbatimão). International Journal of Dentistry, 8, 1-5.

[10] Sanches, A.C., Lopes, G.C., Nakamura, C.V., Dias Filho, B.P. and Mello, J.C. (2005) Antioxidant and Antifungal Activities of Extracts and Condensed Tannins from Stryphnodendron obovatum Benth. Brazilian Journal of Pharmaceutical Sciences, 41, 101-107.

[11] Souza, T.M., Severi, J.A., Silva, V.Y. and Pietro, R.C. (2007) Bioprospecting Antioxidant and Antimicrobial Activity of Stryphnodendron adstringens (Mart.) Coville (Leguminosae-Mimosoidae) Barks. Journal of Basic \& Applied Sciences, 28, 221-226.

[12] Shimizu, B.J., Eurides, D., Beletti, M.E., Freitas, P.M.C. and Chang, R. (2009) 5\% (w/w) Extract Barbatimão in Hydroxyethylcellulose Applied to Skin Wounds in Mice Experimentally Produced Gel. Vet Not, 15, 21-27.

[13] Taiz, L. and Zeiger, E. (2006) Fisiologia Vegetal. 3rd Edition, Artmed, Porto Alegre, 127-145.

[14] Battestin, V., Matsuda, L.K. and Macedo, G.A. (2004) Fontes e aplicações de taninos e tanases em alimentos. Alimentos e Nutrição, 15, 63-72.

[15] Monteiro, J.M.M., Albuquerque, U.P., Araujo, E.L. and Amorim, E.L.C. (2005) Taninos: Uma abordagem da química à ecologia. Química Nova, 28, 892-896. http://dx.doi.org/10.1590/S0100-40422005000500029

[16] Gobbo-Neto, L. and Lopes, N.P. (2007) Plantas medicinais: Fatores de influência no conteúdo de metabólitos secundários. Química Nova, 30, 374-381. http://dx.doi.org/10.1590/S0100-40422007000200026

[17] Araujo, W.L., Dias, P.C., Moraes, G.A.B.K., Celin, E.F., Cunha, R.L., Barros, R.S. and DaMatta, F.M. (2008) Limitations to Photosynthesis in Coffee Leaves from Different Canopy Positions. Plant Physiology and Biochemistry, 46, 884-890. http://dx.doi.org/10.1016/j.plaphy.2008.05.005

[18] Castro, A.H.F., Paiva, R., de Alvarenga, A.A. and Vitor, S.M.M.V. (2009) Calogênese e teores de fenóis e taninos totais em barbatimão [Stryphnodendron adstringens (Mart.) Coville]. Ciência e Agrotecnologia, 33, 385-390. http://dx.doi.org/10.1590/S1413-70542009000200004

[19] Amorim, E.L.C., Nascimento, J.E., Monteiro, J.M., Sobrinho, T.J.S.P., Araújo, T.A.S. and Albuquerque, U.P. (2008) A Simple and Accurate Procedure for the Determination of Tannin and Flavonoid Levels and Some Applications in Ethnobotany and Ethnopharmacology. Functional Ecosystems and Communities, 21, 88-94.

[20] Mace, M.E. and Howell, C.R. (1974) Histochemistry and Identification of Condensed Tannin Precursor in Roots of Cotton Seedlings. Canadian Journal Botany, 52, 2423-2426. http://dx.doi.org/10.1139/b74-314

[21] Stahl, E. and Schild, W. (1981) Pharmazeutiche Biologie 4: Drogennanalyse II. In: Fisher, G., Ed., Innhatsstoffe und isolieniongen, Verlog, Stuttgart, 126-127.

[22] Ferreira, D.F. (2011) Sisvar: A Computer Statistical Analysis System. Ciência e Agrotecnologia, 35, 1039-1042.

[23] Agati, G., Brunetti, C., Di Ferdinando, M., Ferrini, F., Pollastri, S. and Tattini, M. (2013) Functional Roles of Flavonoids in Photoprotection: New Evidence, Lessons from the Past. Plant Physiology and Biochemistry, 72, 35-45. http://dx.doi.org/10.1016/j.plaphy.2013.03.014

[24] Jaakola, L., Määttä-Riihinen, K., Kärenlampi, S. and Hohtola, A. (2004) Activation of Flavonoid Biosynthesis by Solar Radiation in Bilberry (Vaccinium myrtillus L.) Leaves. Planta, 218, 721-728. http://dx.doi.org/10.1007/s00425-003-1161-x

[25] Santos, R.M., Oliveira, M.S., Ferri, P.H. and Santos, S.C. (201) Seasonal Variation in the Phenol Content of Eugenia uniflora L. Leaves. Revista Brasileira de Plantas Medicinais, 13, 85-89. 
[26] Salminen, J.P., Ossipov, V., Haukioja, E. and Pihlaja, K. (2001) Seasonal Variation in the Content of Hydrolysable Tannins in Leaves of Betula pubescens. Phytochemistry, 57, 15-22.

[27] Salminen, J.P., Roslin, T., Karonen, M., Sinkkonen, J., Pihlaja, K. and Pulkkinen, P. (2004) Seasonal Variation in the Content of Hydrolysable Tannins, Flavonoid Glycosides, and Proanthocyanidins in Oak Leaves. Journal of Chemical Ecology, 30, 1693-1711. http://dx.doi.org/10.1023/B:JOEC.0000042396.40756.b7

[28] Lewis, J.L. and Starkey, R.L. (1968) Vegetable Tannins, Their Decomposition and Effects on Decomposition of Some Organic Compounds. Soil Science, 106, 241-247. http://dx.doi.org/10.1097/00010694-196810000-00001

[29] Larcher, W. (2006) Ecofisiologia Vegetal. RiMa, São Carlos, 525-550.

[30] Glasenapp, J.S. (2007) Estrutura genética e fenóis totais de populações naturais de barbatimão (Stryphnodendron adstringens). Dissertação, Mestrado em Genética e Melhoramento de Plantas, Universidade Federal de Viçosa, Viçosa, 65-84.

[31] Jacobson, T.K.B., Garcia, J., Santos, S.C., Duarte, J.B., Farias, J.G. and Kliemann, M. (2005) Influência de fatores edáficos na produção de fenóis totais e taninos de duas espécies de barbatimão (Stryphnodendron sp.). Pesquisa Agropecuária Tropical, 35, 163-169.

[32] Jones, D.H. (1984) Phenylalanine Ammonia-Lyase: Regulation of Its Induction, and Its Role in Plant Development. Phytochemistry, 23, 1349-1359. http://dx.doi.org/10.1016/S0031-9422(00)80465-3

[33] Evans, W.C. (1996) Trease and Evans’ Pharmacognosy. WB Saunders, London, 520-521.

[34] Treutter, D. (2010) Managing Phenol Contents in Crop Plants by Phytochemical Farming and Breeding-Visions and Constraints. International Journal of Molecular Sciences, 11, 807-857. http://dx.doi.org/10.3390/ijms11030807

[35] Xu, C., Zhang, Y., Zhu, L., Huang, Y. and Lu, J. (2011) Influence of Growing Season on Phenolic Compounds and Antioxidant Properties of Grape Berries from Vines Grown in Subtropical Climate. Journal of Agricultural and Food Chemistry, 59, 1078-1086. http://dx.doi.org/10.1021/jf104157z

[36] Otieno, D.O., Schmidt, M.W.T., Kurz-Besson, C., Vale, R.L., Pereira, J.S. and Tenhunen, J.D. (2007) Regulation of Transpirational Water Loss in Quercus suber Trees in a Mediterranean-Type Ecosystem. Tree Physiology, 27, 11791187. http://dx.doi.org/10.1093/treephys/27.8.1179

[37] Pimpão, R.C.S. (2009) Compostos fenólicos e sua actividade antioxidante em espécies de Juniperus: Análise da produção sazonal e sob condições de stresse. Dissertação, Mestrado em Biologia Celular e Biotecnologia, Universidade de Lisboa, Lisboa, 55-64.

[38] Koricheva, J., Larsson, S., Haukioja, E. and Keinanen, M. (1998) Regulation of Woody Plant Secondary Metabolism by Resource Availability: Hypothesis Testing by Means of Meta-Analysis. Oikos, 83, 212-226. http://dx.doi.org/10.2307/3546833 
Scientific Research Publishing (SCIRP) is one of the largest Open Access journal publishers. It is currently publishing more than 200 open access, online, peer-reviewed journals covering a wide range of academic disciplines. SCIRP serves the worldwide academic communities and contributes to the progress and application of science with its publication.

Other selected journals from SCIRP are listed as below. Submit your manuscript to us via either submit@scirp.org or Online Submission Portal.
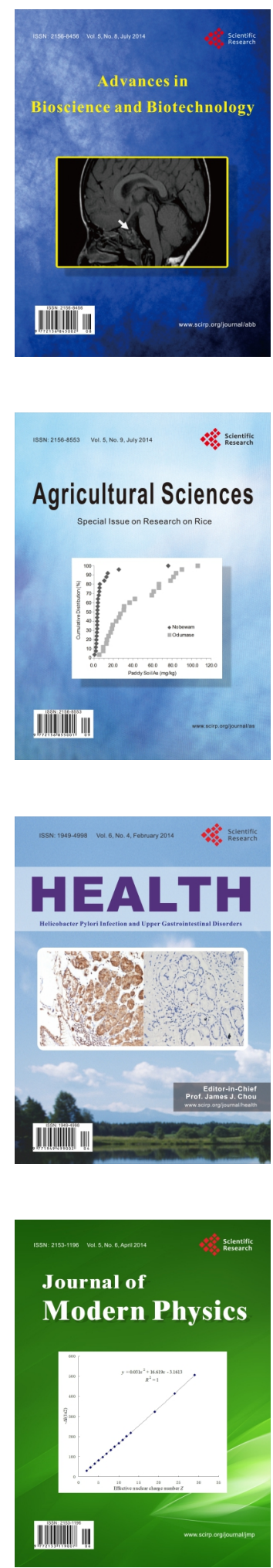
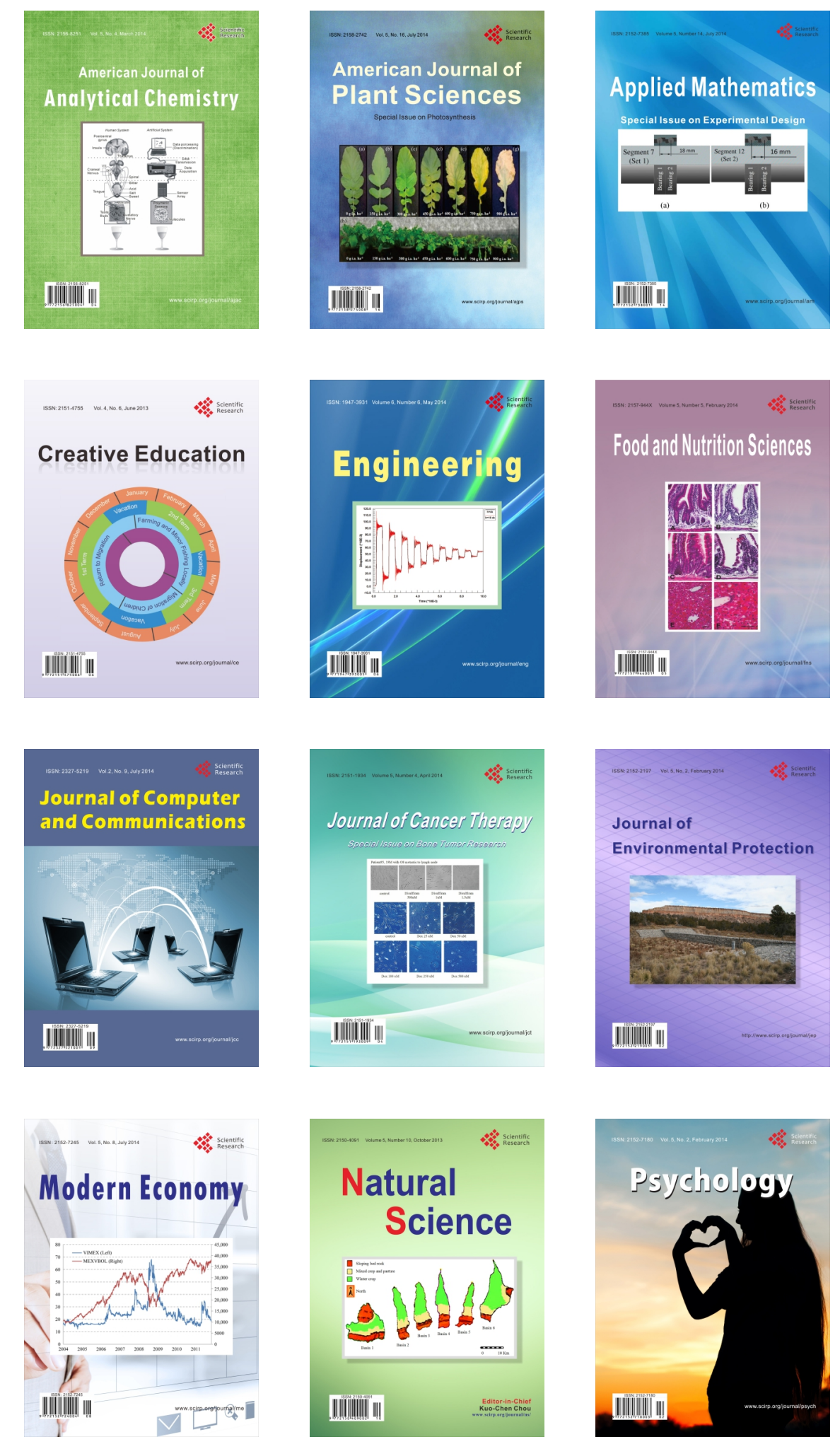